Collection: INCOTW - Sassari, Italy (2017)

"International Congress on Cork Oak Trees and Woodlands"

Guest Editors: Piermaria Corona, Sandro Dettori

\title{
Towards the economic valuation of ecosystem production from cork oak forests in Sardinia (Italy)
}

\author{
Piermaria Corona ${ }^{(1)}$, \\ Valerio Quatrini ${ }^{(1)}$, \\ Matilde Schirru ${ }^{(2)}$, \\ Sandro Dettori ${ }^{(2)}$, \\ Nicola Puletti ${ }^{(1)}$
}

\begin{abstract}
A spatially explicit approach for stand-scale economic valuation of current and future potential of cork forests with respect to ecosystem production is developed and presented. The approach, which relies in large part on the mensuration of stand top height and number of trees as main drivers, has been tested on the pure cork forests of Sardinia (Italy). The test was conducted to assess the effects of alternative silvicultural options on cork and fodder production, carbon sequestration, and water yield. Under current conditions, the surveyed pure cork oak forest stands in Sardinia are characterized, on average, by an annual economic production of 93 euro ha- $\mathrm{yr}^{-1}$ as concerns cork, 37 euro ha-1 $\mathrm{yr}^{-1}$ as concerns carbon sequestration and 261 euro ha ${ }^{-1} \mathrm{yr}^{-1}$ as concerns water yield. The value of cork production on an 11-year cycle equals 1023 euro ha-1 $^{-1}$ on average. The total economic production values among the tested silvicultural alternatives have proven to be characterized by relatively small differences, due to the trade-offs among the considered goods and services. Therefore, at least under conditions similar to those surveyed, managers may safely rely on different stand density options, without any relevant detrimental effect on total economic production. The tested spatial visualization of the economic values of goods and services production can be useful in supporting forest management planning, e.g., to identify priority areas in order to maximize ecosystem production for local communities. The approach proposed here and tested to this end proves to be readily applicable to other cork contexts with similar characteristics under Mediterranean conditions.
\end{abstract}

Keywords: Forest Management, Cork Production, Fodder Production, Carbon Sequestration, Water Yield

Tools for assessing the economic value of multifunctional production by forest ecosystems have been developed since the middle of the last century (Clawson \& Knetsch 1966). The Economic Accounts for Forestry (European Communities 2000), the System of Environmental-Economic Accounting 2012-Central Framework (UN/EU 2014a), and the System of Environmental Economic Accounting 2012-Experimental Ecosystem Accounting (UN/EU 2014b) are current official proposals concerning the valuation and accounting of forest ecosys-

(1) CREA Research Centre for Forestry and Wood, v.le Santa Margherita 80, I-52100 Arezzo (Italy); (2) Department of Science for Nature and Environmental Resources, University of Sas sari, v. De Nicola, I-07100 Sassari (Italy)

@ Nicola Puletti (nicola.puletti@crea.gov.it)

Received: Jul 18, 2017 - Accepted: Aug 04, 2018

Citation: Corona P, Quatrini V, Schirru M, Dettori S, Puletti N (2018). Towards the economic valuation of ecosystem production from cork oak forests in Sardinia (Italy). iForest 11: 660667. - doi: 10.3832/ifor2558-011 [online 2018-10-04]

Communicated by: Marco Borghetti

tems and their services. Developments expanding these official proposals have been provided by Remme et al. (2015), Sumarga et al. (2015), and Obst et al. (2016). In a distinctive manner, recent research has been directed at the spatial analysis of economic provision of goods and services (Barredo et al. 2015, Ovando et al. 2017), recognizing this as a key step toward identifying the appropriate scale for decision-making.

On the other hand, only few studies (Seidl et al. 2007, Bottalico et al. 2016) have investigated the effects of alternative silvicultural strategies on multifunctional ecosystem production at the operational level of forest management unit (FMU). The possibility of simulating the effect of alternative management strategies on the supply of goods and services at the FMU scale is instead crucial, especially under Mediterranean conditions that are usually characterized by fragmented ownership (Palahi et al. 2008), like in the case of cork oak woodland in Sardinia (Italy).

Various publications can be found about cost-benefit analyses, related to the establishment and management of cork oak stands (Campos et al. 2007, Ovando et al. 2010). However, no information about eco- 
Fig. 1 - Location of the sampled forest management units (coordinate system: GCS_International 1909 - Hayford).

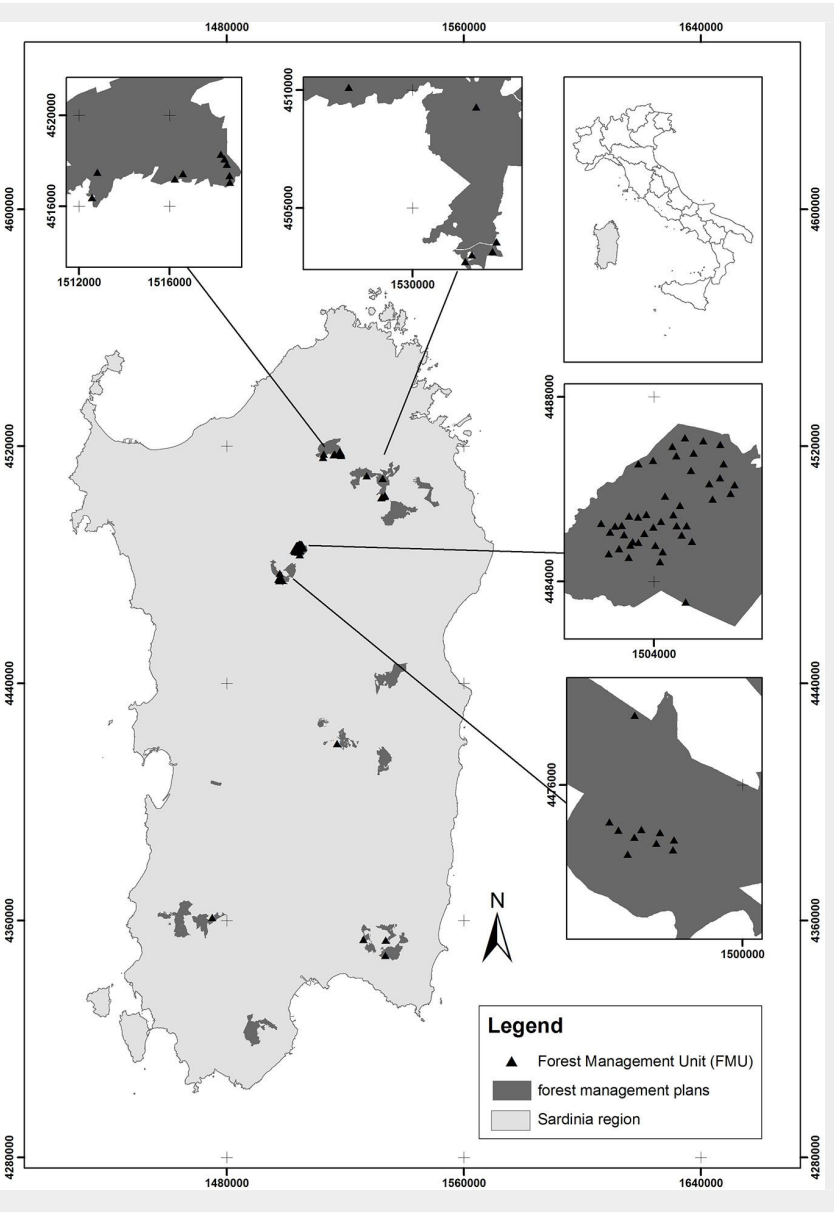

nomic valuation of ecosystem production from cork oak forests in Sardinia, a relevant cork production area in western Mediterranean basin, can be found. To fill this gap, in this study we present a spatially explicit experiment for stand-scale economic valuation of the potential of cork forests in Sardinia to produce a selected set of goods and services. Specifically, we have integrated forest inventory and GISbased data of pure cork forests managed by FoReSTAS (the agency in charge of the forests owned by the Sardinian region, municipalities and, to a lesser extent, private owners) with economic valuation, aiming at economically assessing the influence of alternative silvicultural options on the pro-

vision of cork, fodder, water yield (i.e., aquifer recharge rate), and carbon sequestration. The options taken into account under the compared management scenarios are referred to high-density stands, such as those usually preferred for biodiversity-related motivations, and low-density stands, such as those managed under intensively integrated production approaches (agroforestry systems).

\section{Materials and methods}

\section{Study area}

Sardinia is the second largest island in the Mediterranean Sea, with about 1.6 million inhabitants. According to the Italian na-

Tab. 1 - Statistical summary of dendrometric attributes of the surveyed forest management units. (*): Estimated from tree volumes, according to Federici et al. (2008).

\begin{tabular}{|lrrrr|}
\hline Stand attribute & Min & Max & Mean & Std. Dev. \\
\hline Number of cork trees $\left(\mathrm{n} \mathrm{ha}^{-1}\right)$ & 59 & 1500 & 539.9 & 234.1 \\
\hline Number of productive cork trees $\left(\mathrm{n} \mathrm{ha}^{-1}\right)$ & 20 & 850 & 418.3 & 207.1 \\
\hline Tree diameter $(\mathrm{cm})$ & 10.0 & 32.0 & 24.0 & 5.1 \\
\hline Tree height $(\mathrm{m})$ & 3.0 & 10.0 & 6.2 & 1.3 \\
\hline Stand top height $(\mathrm{m})$ & 5.0 & 14.0 & 9.1 & 1.6 \\
\hline Basal area $\left(\mathrm{m}^{2} \mathrm{ha}^{-1}\right)$ & 3.9 & 62.3 & 26.0 & 12.0 \\
\hline Basal area increment rate $(\%)$ & 1.2 & 4.0 & 1.7 & 0.4 \\
\hline Above-ground tree carbon ${ }^{*}\left(\mathrm{Mg} \mathrm{ha}^{-1}\right)$ & 7.4 & 110.7 & 47.5 & 22.9 \\
\hline Cork age $(\mathrm{yr})$ & 2 & 15 & 8.6 & 3.9 \\
\hline Cork thickness $(\mathrm{cm})$ & 0.5 & 9.0 & 3.1 & 1.6 \\
\hline Debarking height $(\mathrm{cm})$ & 100.0 & 170.0 & 118.4 & 14.0 \\
\hline Mean annual increment of cork mass $\left(\mathrm{kg} \mathrm{ha}^{-1} \mathrm{yr}^{-1}\right)$ & 4.8 & 376.2 & 156.7 & 87.0 \\
\hline
\end{tabular}

tional forest inventory (INFC - http://www. sian.it/inventarioforestale/), nearly 600,000 ha of forests and about 600,000 ha of other wooded land is spread on this island for a total woodland area representing more than half of the land area. Sardinian forests are mainly exploited for wood fuel, grazing, and cork production (http://www. regione.sardegna.it $/ \mathrm{j} / \mathrm{v} / 25$ ? $\mathrm{s}=71168 \& \mathrm{v}=2 \& \mathrm{c}=$ 9\&t=1). One quarter of the forests is characterized by prevailing cork oak, which is in large part represented by pure stands with "composite" structure sensu Zhu et al. (2003), i.e., mono-layered, bi-layered and multi-layered forest stand structures coexist in relatively small areas. A relevant part of these stands is suitable for silvicultural intensification of cork production (e.g., around $60 \%$ in Marghine-Planargia area, according to Corona et al. 1989). Nearly $90 \%$ of the cork oak forests are privately owned, within estates that are 15-20-ha wide on average (http://www.regione.sard egna.it $/ j / v / 25$ ? $s=71168 \& v=2 \& c=9 \& t=1)$. Officially marketed cork production from Sardinia is about 8,000 tons per year, which locally feeds about 25 specialized industrial enterprises and about 30 handicraft firms (with a total of about 850 employees) for an annual production of cork goods valuing more than 20 million euro (http://censi mentoindustriaeservizi.istat.it/).

\section{Field data}

The FoReSTAS Agency has recently completed forest management planning of over 52,000 hectares of their forests (all the management plans can be found at http://www.sardegnaambiente.it/j/v/152?s= $281225 \& v=2 \& c=12078 \& t=1)$, out of which cork oak is predominant on 2,270 ha. As mentioned above, these forest stands are largely characterized by composite structures with multi-aged trees that cannot be strictly assigned to the classical even-aged $v s$. uneven-aged classification. Nearly 930 ha (i.e., 154 FMUs) is composed of stands in which $>80 \%$ of crown coverage is attributed to cork oak, hereafter called pure cork oak stands. For this study, we have considered a random sample of 73 pure cork oak FMUs (Fig. 1), whose average area is 6.9 ha (median area $=5.3 \mathrm{ha}$ ), amounting to a total of 508 ha (i.e., a field sampling of about $0.3 \%$ of the total area with predominant cork oak in Sardinia). Within such FMUs, the following dendrometric data were measured in the year 2014: number of trees (with stem diameter at breast height larger than $2.5 \mathrm{~cm}$ ), number of productive trees (i.e., cork oak trees under harvestable cork production); for each tree: diameter at breast height, diameter increment at breast height, height, tree crown base height, and crown projection; for each productive tree: debarking height, diameter at half debarking height, thickness of cork, and cork age (i.e., number of cork rings). The statistical summary of collected dendrometric data is reported in Tab. 1. 


\section{Silvicultural options}

The economic valuation experiment carried out here is in reference to the 73 sampled pure cork oak FMUs. The annual provision of the considered goods and services was first valued under current conditions. Furthermore, four stand density alternatives were designed resembling the standard models for pure stands of cork oak, as proposed by Vericat et al. (2014). Distinctively, silvicultural options, which were aimed at stands with low (350 trees ha ${ }^{-1}$ ) or high (800 trees ha ${ }^{-1}$ ) number of cork productive trees, were devised. Starting from the current conditions of each FMU, the following two types of options were simulated: (i) a theoretical stand density (called OLDS with reference to the 350 trees $\mathrm{ha}^{-1}$ threshold and OHDS with reference to the 800 trees ha ${ }^{-1}$ threshold) where the number of cork productive trees in a stand is allowed to be reduced or increased without any constraint, and with the stand top height being constant; and (ii) a more realistic stand density (called CLDS with reference to the 350 trees ha $^{-1}$ threshold and CHDS with reference to the 800 trees ha ${ }^{-1}$ threshold) where the number of trees and number of cork productive trees in a stand vary according to practically feasible shortterm management, as described by Fig. 2 .

\section{Supporting prediction models}

\section{Annual cork mass production and above- ground carbon stock}

Two models were developed for predicting the sequestered above-ground carbon stock ( $A G C$, expressed in $M g h^{-1}$ ) and the annual increment of cork mass (AICORK, expressed in $\mathrm{kg} \mathrm{ha}^{-1} \mathrm{yr}^{-1}$ ) of pure cork oak stands, respectively. The annual cork production from a given FMU was modelled as the sum of the annual production (i.e., annual increment of cork) within a cycle by each productive tree in the FMU. The cork mass of each productive tree was assessed by cork thickness, debarking surface, and the application of a density coefficient of

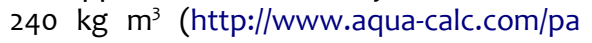
ge/density-table/substance/cork-coma-andblank-solid), while mean annual increment of cork mass was estimated by dividing cork mass by the number of cork rings.

Model development was based on the evidence extracted from data recorded in the surveyed FMUs. Since most stands are characterized by composite structures, (i) stand age cannot be conceived as a suitable predictor, and (ii) stand basal area increment proved to be a rather constant proportion (1.7\%) of stand basal area, without any significant decrement at increasing values of basal area (Pearson's correlation coefficient between stand basal area increment and stand basal area is $r=-0.172, p=$ 0.15 ; no significant correlation was found even after considering the transformations of stand basal area according to power values $0.5,2$, and -1). Such a constant increment rate of $0.017 \mathrm{yr}^{-1}$ can be safely ex- tended to biomass and carbon stock increment. In addition, (iii) under the range of conditions of the surveyed stands, the annual cork increment of individual trees was not influenced by the total number of trees in the stand $(r=-0.128, p=0.28$; no significant correlation was found even considering the transformations of total number of trees according to power values $0.5,2$ and $-1)$ or by the cork age $(r=0.038, p=0.75$; no significant correlation was found even considering the transformations of cork age according to power values $0.5,2$ and $-1)$, while it was significantly correlated $(r=$ $0.352, p<0.01$ ) to the stand top height (the mean height of the dominant trees in a stand), which is taken as an indicator of site productive capacity in uneven-aged stands (West 2009); (iv) annual increment of cork mass at stand level was significantly correlated to the stand top height $(r$ $=0.442, p<0.001$ ) and the total number of productive trees in the stand $(r=0.811, p<$ 0.001); (v) above-ground carbon stock at stand level was significantly correlated to the stand top height $(r=0.290, p=0.01)$ and the number of trees $(r=0.721, p<$ 0.001); (vi) stand basal area proved to be highly correlated to the number of trees $(r$ $=0.777, \mathrm{p}<0.001)$, the number of productive trees $(r=0.665, p<0.001)$, and the stand top height $(r=0.272, p=0.02)$.

The development of the models to predict AGC and AICORK was carried out by linear regression, exploiting the number of trees (NT, expressed per hectare) and the stand top height ( $\mathrm{TH}$, expressed in $\mathrm{m}$ ), respectively, as predictors for AGC and the number of productive cork trees (NPT, expressed per hectare) and $\mathrm{TH}$ as predictors for AICORK. Stand basal area was not considered as a predictor because of its close collinearity with NT, NPT and TH, while being a parameter that is much less easily assessable on a large scale than NT, NPT and TH (see also Discussion and conclusions). Model predictors were included as measured values and their transformations, according to power values $0.5,2$ and -1 . They were selected by the conventional step- wise method (Draper \& Smith 1981) by adopting a critical value of $F$ in the process of inclusion equal to that of the process of elimination; the level of significance of critical $F$ was set equal to 0.90 to ensure the selection of few predictors.

\section{Annual water yield provision}

The approach proposed by InVEST (http://www.naturalcapitalproject.org/inve st/) was followed here. Specifically, the InVEST ver. 3.3.2 water yield model was used. A full documentation of the model is reported by Sharp et al. (2015) and an informative application example can be found in Redhead et al. (2016). Among the micrometeorological factors driving the water yield model, the plant (vegetation) evapotranspiration coefficient $K$ (SánchezCanales et al. 2012) is directly associated to the forest stand structure, particularly with regard to crown coverage (Sharp et al. 2015). Under this basis and following the literature pertaining to Quilchano et al. (2008) and Pérez-Ramos et al. (2008), Fig. S1 (Supplementary material) reports the trend of $K$ in cork oak stands as a function of crown coverage from TH and NT.

\section{Annual fodder production}

The forage units (FU) annually produced in forests is known to be significantly determined by stand development and tree density (Clason \& Sharrow 2005). Under this assumption and on the basis of literature pertaining to Dettori et al. (2001), Fig. S2 (Supplementary material) shows the trend of produced FU per year in cork oak stands as a function of TH and NT. With regard to the economic valuation of such production, it must be considered that in Sardinia grazing is practiced either for free on self-owned land or as a public right of local communities or against a token tax paid by forest users to local authorities. However, the taxes are nominal, so they do not reflect the real value of grazing. On the other hand, there is no established market for grazing rents. An approach based on the substitute goods approach was used

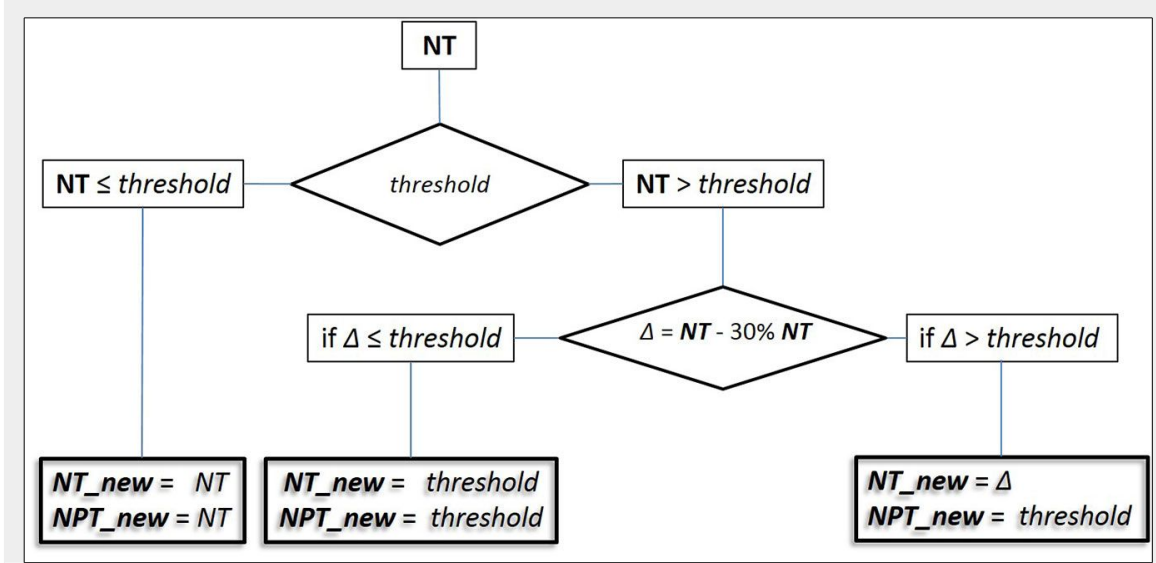

Fig. 2 - Flow chart of the CLDS and CHDS silvicultural models. (NT): number of trees (NPT): number of cork productive trees. See text for further explanation. 
Tab. 2 - Results of the regression analysis carried out to estimate the numerical coefficients of the established AICORK and AGC models $\left(r^{2}=\right.$ coefficient of determination; $\mathrm{SEE}=$ standard error of the estimate, in $\mathrm{kg} \mathrm{ha}^{-1} \mathrm{yr}^{-1}$ for AICORK and $\mathrm{Mg} \mathrm{ha}^{-1}$ for AGC).

\begin{tabular}{lcc}
\hline Model & $r^{2}$ & SEE \\
\hline AICORK $=-217.5+11.34 \cdot\ulcorner\mathrm{NPT}+50.36 \cdot\ulcorner\mathrm{TH}$ & 0.687 & 49.3 \\
$A G C=9.712+3.100 \cdot / \mathrm{NT}-(287.2 / \mathrm{TH})$ & 0.600 & 14.6 \\
\hline
\end{tabular}

Tab. 3 - Leave-One-Out validation of the established AGC and AICORK models.

\begin{tabular}{lccc}
\hline Model & $\begin{array}{c}\text { Mean of } \\
\text { deleted residuals }\end{array}$ & $\begin{array}{c}\text { Mean of absolute } \\
\text { deleted residuals }\end{array}$ & $\begin{array}{c}\text { Explained } \\
\text { variance (\%) }\end{array}$ \\
\hline $\begin{array}{l}\text { Annual increment of cork mass } \\
\left(\mathrm{kg} \mathrm{ha}^{-1} \mathrm{yr}^{-1}\right)\end{array}$ & 0.06 & 38.68 & 66.4 \\
Above ground carbon $\left(\mathrm{Mg} \mathrm{ha}^{-1}\right)$ & 0.05 & 10.91 & 57.7 \\
\hline
\end{tabular}

by Croitoru (2007) for the economic valuation of fodder produced by the Mediterranean forests. It was also adopted by Mavsar et al. (2014) through the conversion of $\mathrm{FU}$ into an equivalent of barley, based on a comparison of nutrients' content ( $1 \mathrm{FU} \approx 1 \mathrm{~kg}$ of barley). The latter ap proach clearly conveys an economic overvaluation of fodder production and was used here just for a relative comparison of the values provided by Croitoru (2007) and among the considered management alternatives.

\section{Pricing}

A given pure cork oak stand was priced as the sum of values from annual cork production, annual carbon sequestration, and annual water yield. The reference year for pricing was 2016. AICORK by standard cork quality proportions (first quality $=30 \%$; second quality $=$ $40 \%$; third quality $=30 \%$ ) and multiplying the mass of these quality classes by their stumpage prices, we got 0.95 euro $\mathrm{kg}^{-1}$, 0.50 euro $\mathrm{kg}^{-1}$ and 0.20 euro $\mathrm{kg}^{-1}$ respectively (reference: http://www.ar.camcom.it /modules/wfdownloads/singlefile.php?cid= 70\&lid=1491). With regard to annual carbon sequestration, we multiplied AGC by the in crement rate of $0.017 \mathrm{yr}^{-1}$ and a value of 44 euro per $\mathrm{Mg}$ of C (reference: http://www. crea.gov.it/wp-content/uploads/2016/08/M erc_Forestale_Carbonio_15.pdf, see also
For annual cork production, subdividing

Storti et al. 2015). For annual water yield a value of 0.0637 euro $\mathrm{m}^{-3}$ was used, which is the average price of water for agricultural irrigation purposes in Sardinia (https:// www.regione.sardegna.it/documenti/1_470 20160127133532.pdf). Finally, for forage unit, a shadow price of 0.3 euro per $\mathrm{kg}$ of barley was used, as suggested by Mavsar et al. (2014), with respect to Mediterranean forests. One has to be warned, however, that we are here valuing fodder that may or may not be consumed by animals, and in the latter case, nobody would pay for this product.

\section{Results}

\section{AICORK and AGC models}

The established models for predicting AICORK and AGC are presented in Tab. 2. The regression coefficients of the AICORK model are significant (at least) at $\mathrm{p}<0.05$, while those of the AGC model are significant at $\mathrm{p}<0.01$. The graphical analysis of the residuals from both the models is reported in Fig. S3 (Supplementary material). The actual reliability of the models was checked by a "leave-one-out" procedure, i.e., by the so-called deleted residuals (for each observation, a deleted residual is calculated by excluding the observation from the calculation of the regression coefficients). The validation results corroborated the established models, which are not only independently proven to provide unbiased

Tab. 4 - Comparison of the mean economic values (expressed in euro ha ${ }^{-1} \mathrm{yr}^{-1}$ ) of the production of selected goods and services from pure cork oak forests managed by the FoReSTAS agency in Sardinia (Italy). Reference year: 2016. (*): Fodder is estimated by the substitute good approach, which may convey overvaluation of the reported absolute economic figures.

\begin{tabular}{lccccccc}
\hline Model & $\begin{array}{c}\text { Cork } \\
(\mathbf{1})\end{array}$ & $\begin{array}{c}\text { Fodder* }^{*} \\
\mathbf{( 2 )}\end{array}$ & $\begin{array}{c}\text { Sub-total } \\
\mathbf{( 3 = 1 + 2 )}\end{array}$ & $\begin{array}{c}\text { Carbon } \\
\text { sequestration } \\
\mathbf{( 4 )}\end{array}$ & $\begin{array}{c}\text { Sub- } \\
\text { total } \\
\mathbf{( 5 = 4 + 3 )}\end{array}$ & $\begin{array}{c}\text { Water } \\
\text { yield } \\
\mathbf{( 6 )}\end{array}$ & $\begin{array}{c}\text { Total } \\
\mathbf{( 5 + 6 )}\end{array}$ \\
\hline Current condition & 93.0 & 36.7 & 129.6 & 36.6 & 166.2 & 260.7 & 426.9 \\
\hline CLDS model & 77.5 & 39.4 & 116.8 & 29.6 & 146.4 & 267.7 & 414.0 \\
CHDS model & 105.0 & 36.7 & 141.7 & 36.3 & 178.1 & 260.7 & 438.7 \\
\hline OLDS model & 81.0 & 40.7 & 121.7 & 27.3 & 149.1 & 272.4 & 421.4 \\
OHDS model & 140.2 & 30.0 & 170.2 & 49.5 & 219.8 & 249.9 & 469.7 \\
\hline
\end{tabular}

predictions, but also explain a high portion of the variability of AICORK and AGC (Tab. 3). The percent ratios between the mean of absolute deleted residuals and the mean of AICORK and AGC, which provide a figure of the magnitude of error when predicting AICORK and AGC for single stands, appear quite satisfactory (given the variability of these two stand attributes), being equal to $25 \%$ and $23 \%$, respectively.

\section{Economic value of ecosystem production}

The economic value per hectare of annual production of the considered goods and services in the sampled pure cork stands is presented in Tab. 4. The values were in the range reported by Croitoru (2007) with regard to fodder and relatively lower with respect to cork. The value of fodder was also similar to that assessed by grazing rents in the cork oak woodland of northern Tunisia (Campos et al. 2009). Overall, under current conditions, the surveyed 73 pure cork oak FMUs were characterized by an annual economic production of 47,248 euro $\mathrm{yr}^{-1}$, 18,607 euro $\mathrm{yr}^{-1}$, and 132,485 euro $\mathrm{yr}^{-1}$ in relation to cork, carbon sequestration, and water yield respectively. On average, in the sampled FMUs, the value of cork production on an 11-year cycle equaled 1,023 euro ha ${ }^{-1}$. Fig. 3 shows the map of the economic value of annual ecosystem production for selected FMUs under current conditions and the simulated silvicultural options.

The models adopted for quantifying the physical provision of the considered goods and services as well as the adopted unitary prices obviously exert a direct significant influence on the assessed economic values, as can be observed by their wide range under the sensitivity analysis carried out by adding or subtracting a percent equal to $50 \%$ to the quantities or the prices (Fig. 4 see Tab. S1-S2 in supplementary materials), as suggested by Kreuter et al. (2001) and Wang et al. (2014).

Under the assumed conditions and pricing, annual water yield outweighs the economic value of all the other goods and services examined here. Cork production ranks second in terms of economic value, while, under current conditions, the annual provision of fodder and the carbon sequestration rank almost equal, albeit, given the likely overestimation induced by the adopted valuation approach, it is likely that fodder actually ranks the lowest in terms of economic value. Cork production increases in the high density scenario as well as carbon sequestration, while the opposite holds true for fodder and water yield. On the whole, the most productive silvicultural options are those oriented toward high-density stands, at least under the assumed considerations and pricing conditions, though the overall range of total economic values from the considered goods and services is relatively small under the investigated alternatives, since there is a clear trade-off among the considered 
Fig. 3 - Map of the economic values of total annual production of the considered goods and services in selected pure cork oak forest management units in Sardinia, under current conditions and simulated management scenarios: (i) OLDS, theoretical silvicultural option with reference to 350 trees ha'; (ii) OHDS, theoretical silvicultural option with reference to 800 trees ha'; (iii) CLDS, realistic silvicultural option with reference to 350 trees ha ${ }^{-1}$; (iv) CHDS, realistic silvicultural option with reference to 800 trees ha $^{-1}$ (see text for explanation; coordinate system: GCS International 1909 - Hayford).

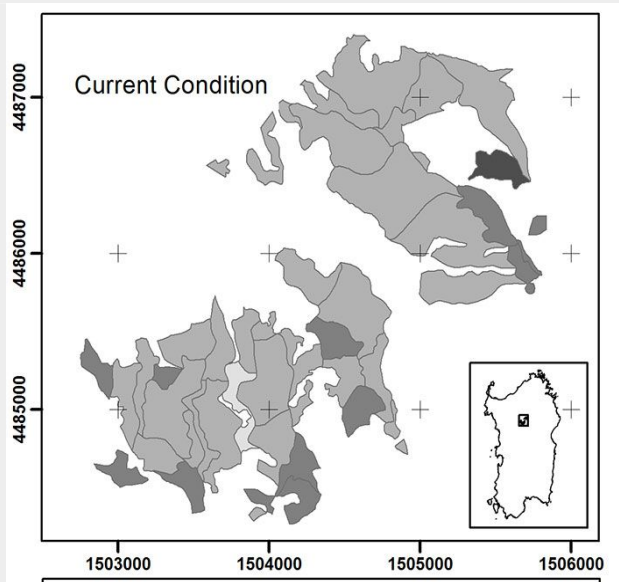

\section{Legend}

$\mathrm{EV}=$ economic value $\left(€ \mathrm{ha}^{-1}\right)$

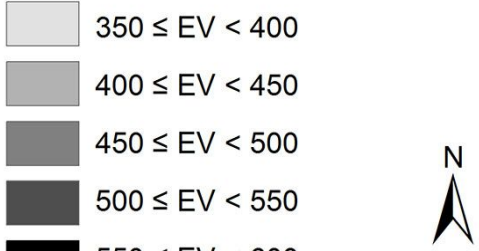

$550 \leq \mathrm{EV}<600$
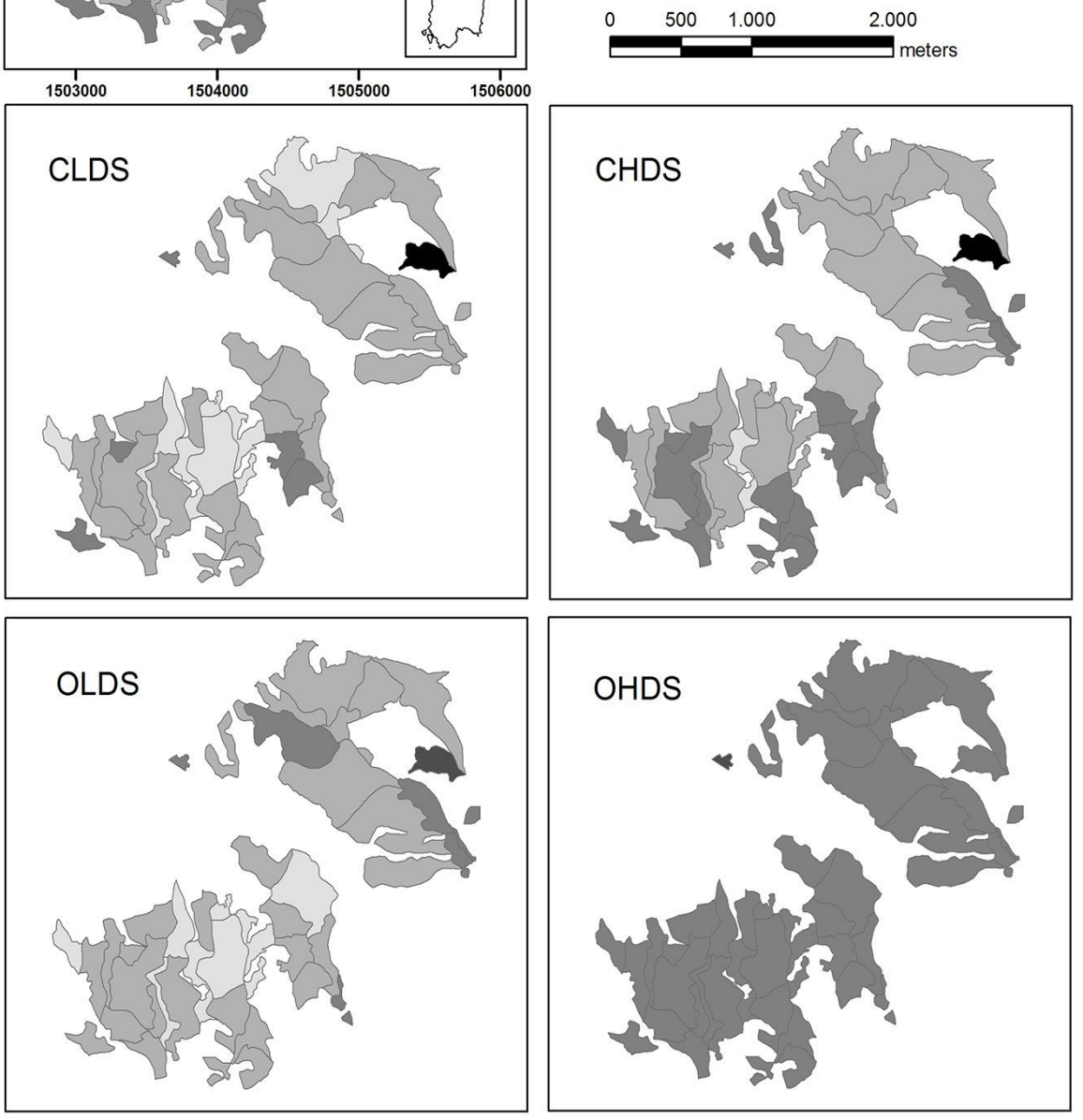

goods and services with respect to stand density. Its increase, under the examined conditions, exerts positive effects on cork production and carbon sequestration at stand level and negatively affects fodder production and water yield.

\section{Discussion and conclusions}

This study, carried out on a large sample of FMUs representative of pure cork oak stands with composite structure in Sardinia, contributes to the ongoing debate on interactions and synergies between goods and services associated with the management of Mediterranean forests (Mavsar et al. 2014). Few studies (Campos et al. 2009, Ovando et al. 2010, Bugalho et al. 2011, 2016, Anaya-Romero et al. 2016) can be found in literature specifically with regard to valuation of ecosystem production from cork oak forests, and none, at least to our knowledge, has investigated the effects of

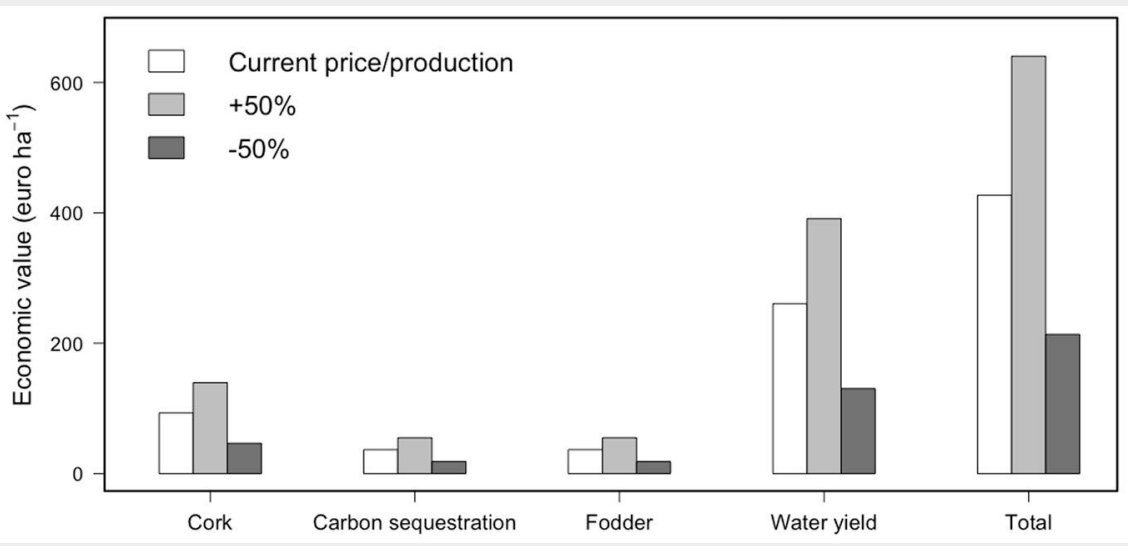

Fig. 4 - Range of the economic values of annual production of the considered goods and services under sensitivity analysis carried out by adding or subtracting a percent equal to $50 \%$ to the quantity or to the unitary price of such goods and services. Fodder is estimated by the substitute good approach, which may convey overvaluation of the reported absolute economic figures. 
alternative silvicultural strategies on provided goods and services at the operational level of FMUs. The methodological framework adopted here is quite similar to those developed by Seidl et al. (2007) and Bottalico et al. (2016), which, however, consider quite different goods and services from those considered here, besides carbon sequestration. Bugalho et al. (2011, 2016) described cork oak savanna-related payment for ecosystem services mechanisms and identified areas for maximizing such services, but did not deal with valuation at the level of forest management unit, as this study has done. Similarly, Anaya-Romero et al. (2016) provided an estimation of ecosystem production in south Spain at the large-scale level of the socalled eco-management units. On the other hand, Ovando et al. (2010) dealt mainly with the estimation of the private net benefits from new afforestation on marginal shrubland and cropland with cork oaks in Spain, while the analyses from Campos et al. (2007) focused on total income supplied by cork oak woodland activities in Tunisia, not taking into account unmarketed services (e.g., carbon sequestration) like this study.

Dealing with a relatively still not explored field, many of the assumptions and simplifications adopted here were uncertain. For instance, to evaluate the function of water cycle regulation exerted by cork oak forests by pricing their water yield with respect to agricultural irrigation is a quite strong assumption, and probably one of the main reasons as to why water yield shows the highest production value among all the productions here considered. Another issue is that cork age and the number of previous debarking operations are usually considered to have an influence on cork production, at least for predominantly even-aged stands, although it is not always possible to count on that information being included in the cork production model: in the considered composite stands, characterized by multi-aged trees, the first attribute did not prove to exert a significant influence on individual cork production, while the second could not be assessed at stand level since each tree had a different debarking history. A further critical issue is that the method adopted here for assessing fodder economic value can convey overvaluation, not only because the substitute good approach is used, but also because the valued production may or may not be consumed.

On the other hand, major advancements are provided by this study. From a methodological point of view, the proposed standscale valuation approach does not refer to the age of the forest stands, a parameter most often taken into account for ecosystem production modeling but rather meaningless under Mediterranean conditions, because, except managed coppices and forest plantations, the Mediterranean forest stands are usually characterized by composite structures with multi-aged trees (Nocentini \& Coll 2013). On the contrary, the ecosystem production modeling developed here relies in large part on the assessment of stand top height and number of trees as main drivers: such parameters are relatively feasibly retrievable even over large areas, e.g., by remote sensing tools like (manned or unmanned) airborne laser scanning (Corona et al. 2012, Montaghi et al. 2013). From an operational point of view, the proposed spatial visualization of the economic values of production of goods and services (Fig. 3) is a useful support for forest management planning, e.g., to project selected productions by cork oak stands in the future in order to improve the effectiveness of management strategies toward their preservation and enhancement and/or identify priority areas that would maximize ecosystem production for local communities. From a management point of view, the total economic production values among the tested silvicultural alternatives (Tab. 4) has proved to be characterized by relatively small differences: therefore, at least under conditions similar to those of the FMUs here surveyed, managers may safely rely on different stand density options, without any relevant detrimental effect on total economic production of the considered goods and services. From a governance point-of view, the data and tools provided here may be effective toward the establishment of local schemes of payments for ecosystem services (e.g., with respect to water yield and carbon sequestration), which, in turn may support the owners in the light of management practices contributing to the conservation and sustainable use of cork oak woodland (Bugalho et al. 2011).

From a general point of view, the obtained economic values of ecosystem production and the proposed valuation approach are readily portable to other contexts with similar characteristics to those investigated here (pure cork oak stands with composite stand structure). Specifically, using the data from the FoReSTAS management plans as reference, it can be inferred that nearly half of the cork forests in Sardinia possess the range of conditions for which the economic valuation developed here can be directly applied to. According to INFC, a similar inference is also valid with respect to other Italian regions, and might be even applied to those cork oak woodlands across the western Mediterranean basin whose predominant stands are characterized by relatively closed canopies and not savanna-like (e.g., northeastern Spain).

The analyses carried out could provide important information on how to balance economic production from alternative goods and services according to management strategies and landscape characteristics (Cademus et al. 2014), enabling decision-makers, stakeholders and landscape planners to better guide management strategies and decisions (Palma et al. 2015, Santos et al. 2016). Further work is required in order to consider other services from cork oak stand management, such as soil conservation, landscape quality and recreation, which have not been evaluated here but that, from the socio-economical point of view, may be very meaningful in many Mediterranean contexts.

\section{Acknowledgements}

This work was supported by the Sardinia Region under the project "Multifunzionalità delle foreste a quercia da sughero in Sardegna" [Multifunctionality of cork oak forests in Sardinia], funded within L.R. n. 7/2007 "Promozione della ricerca scientifica e della innovazione tecnologica in Sardegna / Tender no. 2".

We would like to sincerely thank two anonymous reviewers who helped in significantly improving earlier versions of the manuscript. We would also like thanking Piermatteo Barone (American University of Rome) for the revision of the English text.

\section{References}

Anaya-Romero $M$, Muñoz-Rojas $M$, Ibáñez $B$, Marañón T (2016). Evaluation of forest ecosystem services in Mediterranean areas. A regional case study in South Spain. Ecosystem Services 20: 82-90. - doi: 10.1016/j.ecoser.2016.07.002 Barredo Jl, Bastrup-Birk A, Teller A, Onaindia M, Fernández De Manuel $B$, Madariaga I, Rodríguez-Loinaz $G$, Pinho $P$, Nunes $A$, Ramos A, Batista M, Mimo S, Cordovil C, Branquinho C, GrêtRegamey A, Bebi P, Hanna Brunner S, Weibel B, Kopperoinen L, Itkonen $P$, Viinikka A, Chirici G, Bottalico F, Pesola L, Vizzarri M, Garfì V, Antonello L, Barbati A, Corona P, Cullotta S, Giannico V, Lafortezza R, Lombardi F, Marchetti $M$, Nocentini S, Riccioli F, Travaglini D, Sallustio L, Rosário I, Von Essen M, Nicholas KA, Máguas C, Rebelo R, Santos-Reis M, Santos-Martín F, Zorrilla-Miras P, Montes C, Benayas J, MartínLópez B, Snäll T, Berglund H, Bengtsson J, Moen J, Busetto L, San-Miguel-Ayanz J, Thurner M, Beer C, Santoro M, Carvalhais N, Wutzler T, Schepaschenko D, Shvidenko A, Kompter A, Ahrens B, Levick SR, Schmullius C (2015). Mapping and assessment of forest ecosystems and their services. Applications and guidance for decision making in the framework of MAES. EUR 27751 EN, EC Joint Research Centre, Ispra, VA, Italy, pp. 81. - doi: 10.2788/869265

Bottalico F, Pesola L, Vizzarri M, Antonello L, Barbati A, Chirici G, Corona P, Cullotta S, Garfi V, Giannico V, Lafortezza R, Lombardi F, Marchetti M, Nocentini S, Riccioli F, Travaglini D, Sallustio L (2016). Modeling the influence of alternative forest management scenarios on wood production and carbon storage: a case study in the Mediterranean region. Environmental Research 144: 72-87. - doi: 10.1016/j.en vres.2015.10.025

Bugalho MN, Caldeira MC, Pereira JS, Aronson J, Pausas JG (2011). Mediterranean cork oak savannas require human use to sustain biodiversity and ecosystem services. Frontiers in Ecology and the Environment 9 (5): 278-286. - doi: $10.1890 / 100084$ 
Bugalho MN, Dias FS, Brinas B, Cerdeira JO (2016). Using the high conservation value forest concept and Pareto optimization to identify areas maximizing biodiversity and ecosystem services in cork oak landscapes. Agroforestry Systems 90: 35-44. - doi: 10.1007/s10457-015-98 $14-x$

Cademus R, Escobedo FJ, McLaughlin D, Abd-Elrahman A (2014). Analyzing trade-offs, synergies, and drivers among timber production, carbon sequestration, and water yield in Pinus elliotii forests in Southeastern USA. Forests 5: 1409-1431. - doi: 10.3390/f5061409

Campos P, Daly H, Ovando P (2007). Cork oak forest management in Spain and Tunisia: two case studies of conflicts between sustainability and private income. International Forestry Review 9 (2): 610-626. - doi: 10.1505/ifor.9.2.610

Campos P, Ovando P, Chebil A, Daly-Hassen H (2009). Cork oak woodland conservation and household subsistence economy challenges in Northern Tunisia. In: "Cork Oak Woodlands on the Edge Ecology, Adaptive Management, and Restoration" (Aronson J, Pereira JS, Pausas JG eds). Island Press, Washington, DC, USA, pp. 165-176.

Clason T, Sharrow S (2005). Silvopastoral practices. In: "North American Agroforestry: An Integrated Science and Practice" (Garrett HE, Rietbeld WJ, Fisher RF eds). American Society of Agronomy Inc, Madison, WI, USA, pp. 119-147.

Clawson M, Knetsch JL (1966). Economics of outdoor recreation. Johns Hopkins University Press, Baltimore, MD, USA, pp. 328.

Corona P, Eccher A, Ferrara A, Piccini C (1989). Individuazione di modelli gestionali per alcune tra le più rappresentative formazioni forestali della Sardegna [Identifying management options for some of the most representative forest types in Sardinia]. In: "Sistemi agricoli marginali - Lo Scenario Marghine Planargia”. CNR, Sassari, Italy, pp. 85-136. [in Italian]

Corona P, Cartisano R, Salvati L, Chirici G, Floris A, Di Martino P, Marchetti M, Scrinzi G, Clementel F, Travaglini D, Torresan C (2012). Airborne laser scanning to support forest resource management under alpine, temperate and Mediterranean environments in Italy. European Journal of Remote Sensing 45: 27-37. - doi: 10.5721/EuJRS20124503

Croitoru L (2007). Valuing the non-timber forest products in the Mediterranean region. Ecological Economics 63: 768-775. - doi: 10.1016/j.ecol econ.2007.01.014

Dettori S, Filigheddu MR, Gutierrez M (2001). La coltivazione della quercia da sughero [Cork oak cultivation]. Dipartimento di Economia e Sistemi Arborei, Università di Sassari, Sassari, Italy, pp. 131. [in Italian]

Draper NR, Smith H (1981). Applied regression analysis ( $2^{\text {nd }}$ edn). Wiley, New York, USA, pp. 709.

European Communities (2000). Manual on the economic accounts for agriculture and forestry EEA/EAF 97 (Rev. 1.1). EC, EUROSTAT, Luxembourg, pp 172.

Federici S, Vitullo M, Tulipano S, De Lauretis R, Seufert $G$ (2008). An approach to estimate carbon stocks change in forest carbon pools under the UNFCCC: the Italian case. iForest - Biogeosciences and Forestry 1 (2): 86-95. - doi: 10.3832/

\section{iforo457-0010086}

Gatto P, Pettenella D, Secco L (2009). Payments for forest environmental services: organisational models and related experiences in Italy. iForest - Biogeosciences and Forestry 2: 133-139. doi: 10.3832/ifor0504-002

Gonzalez J, Luque S, Poggio L, Smith R, Gimona A (2016). Spatial Bayesian belief networks as a planning decision tool for mapping ecosystem services trade-offs on multifunctional forested landscapes. Environmental Research 144: 15-26. - doi: 10.1016/j.envres.2015.11.009

Kreuter UP, Harris HG, Matlock MD, Lacey RE (2001). Change in ecosystem service values in the San Antonio area, Texas. Ecological Economics 39: 333-346. - doi: 10.1016/S0921-8009 (01)00250-6

Marchetti M, Vizzarri M, Lasserre B, Sallustio L, Tavone A (2014). Natural capital and bioeconomy: challenges and opportunities for forestry. Annals of Silvicultural Research 38: 62-73. - doi: 10.12899/asr-1013

Mavsar R, Herreros F, Varela E, Gouriveau F, Duclercq M (2014). Methods and tools for socioeconomic assessment of goods and services provided by Mediterranean forest ecosystems. Plan Bleu pour l'environnement et le développement en Méditerranée, Valbonne, France, pp 105.

Montaghi A, Corona P, Dalponte M, Gianelle D, Chirici G, Olsson H (2013). Airborne laser scanning of forest resources: an overview of research in Italy as a commentary case study. International Journal of Applied Earth Observation and Geoinformation 23: 288-300. - doi: 10.1016/j.jag.2012.10.002

Nocentini S, Coll L (2013). Mediterranean forests: human use and complex adaptive systems. In: "Managing Forests as Complex Adaptive Systems. Building Resilience to the Challenge of Global Change" (Messier C, Puettmann KJ, Coates KD eds). The Earthscan Forest Library (series), Routledge, London and New York, pp. 214-243. [online] URL: http://books.google. com/books?id=D5SodmXoOasC

Obst C, Hein L, Edens B (2016). National accounting and the valuation of ecosystem, assets and their services. Environmental and Resource Economics 64 (1): 1-23. - doi: 10.1007/s10640-01 5-9921-1

Ovando P, Campos P, Oviedo JL, Montero G (2010). Private net benefits from afforesting marginal cropland and shrubland with cork oaks in Spain. Forest Science 56 (6): 567-577. [online] URL: http://academic.oup.com/forest science/article/56/6/567/4604483

Ovando P, Caparros A, Diaz-Balteiro L, Pasalodos M, Beguería S, Oviedo JL, Montero G, Campos $P$ (2017). Spatial valuation of forests' environmental assets: an application to Andalusian silvopastoral farms. Land Economics 93: 87-108. doi: 10.3368/le.93.1.87

Palma JH, Paulo JA, Faias SP, Garcia-Gonzalo J, Borges JG, Tomé M (2015). Adaptive management and debarking schedule optimization of Quercus suber L. stands under climate change: case study in Chamusca, Portugal. Regional Environmental Change 15 (8): 1569-1580. - doi: 10.1007/s10113-015-0818-x

Pérez-Ramos IM, Zavala MA, Marañón T, DíazVilla MD, Valladares F (2008). Dynamics of un- derstorey herbaceous plant diversity following shrub clearing of cork oak forests: a five-year study. Forest Ecology and Management 255: 3242-3253. - doi: 10.1016/j.foreco.2008.01.069 Quilchano C, Marañón T, Pérez-Ramos IM, Noejovich L, Valladares F, Zavala MA (2008). Patterns and ecological consequences of abiotic heterogeneity in managed cork oak forests of Southern Spain. Ecological Research 23: 127139. - doi: 10.1007/s11284-007-0343-6

Palahi M, Mavsar R, Gracia C, Birot Y (2008). Mediterranean forests under focus. International Forestry Review 10: 676-688. - doi: 10.1505/ifor.10.4.676

Redhead JW, Stratford C, Sharps K, Jones L, Ziv G, Clarke D, Oliver TH, Bullock JM (2016). Empirical validation of the InVEST water yield ecosys tem service model at a national scale. The Science of the Total Environment 569-570: 14181426. - doi: 10.1016/j.scitotenv.2016.06.227

Remme RP, Edens B, Schröter M, Hein L (2015). Monetary accounting of ecosystem services: a test case for Limburg Province, the Netherlands. Ecological Economics 11: 116-128. - doi: 10.1016/j.ecolecon.2015.02.015

Sánchez-Canales M, López Benito A, Passuello A, Terrado M, Ziv G, Acuña $V$, Schuhmacher $M$, Elorza FJ (2012). Sensitivity analysis of ecosystem service valuation in a Mediterranean watershed. The Science of the Total Environment 440: 140-53. - doi: 10.1016/j.scitotenv.2012.07. 071

Santos MJ, Baumann M, Esgalhado C (2016). Drivers of productivity trends in cork oak woodlands over the last 15 years. Remote Sensing 8 (6): 486. - doi: 10.3390/rs8060486

Seidl R, Rammer W, Jäger D, Currie WS, Lexer MJ (2007). Assessing trade-offs between carbon sequestration and timber production within a framework of multi-purpose forestry in Austria. Forest Ecology and Management 248: 64-79. - doi: 10.1016/j.foreco.2007.02.035 Sharp R, Tallis HT, Ricketts T, Guerry AD, Wood SA, Chaplin-Kramer R, Nelson E, Ennaanay D, Wolny S, Olwero N, Vigerstol K, Pennington D, Mendoza G, Aukema J, Foster J, Forrest J, Cameron D, Arkema K, Lonsdorf E, Kennedy C, Verutes G, Kim CK, Guannel G, Papenfus M, Toft J, Marsik M, Bernhardt J, Griffin R, Glowinski K, Chaumont N, Perelman A, Lacayo M, Mandle L, Hamel P, Vogl AL, Rogers L, Bierbower W (2015). InVEST 3.2.0 User's guide. The natural capital project. The Nature Conservancy, and World Wildlife Fund, Stanford University, University of Minnesota, USA, pp. 361.

Storti D, Brotto L, Pettenella D, Chiriacò MV, Maluccio S, Maso D, Corradini G, Portaccio A, Perugini L, Romano R (2015). Stato del mercato forestale del carbonio in Italia 2015 [The condition of the carbon forest market in Italy 2015]. Nucleo Monitoraggio del Carbonio, CREA, Rome, pp. 40. [in Italian]

Sumarga E, Hein L, Edens B, Suwarno A (2015). Mapping monetary values of ecosystem services in support of developing ecosystem accounts. Ecosystem Services 12: 71-83. - doi: 10.1016/j.ecoser.2015.02.009

UN/EU (2014a). System of environmental-economic accounting 2012 - central framework. United Nations, European Union, Food and Agriculture Organization of the United Nations, 
International Monetary Fund, Organisation for Economic Co-operation and Development, The World Bank, New York, USA, pp. 378.

UN/EU (2014b). System of environmental-economic accounting 2012 - experimental ecosystem accounting. United Nations, European Union, Food and Agriculture Organization of the United Nations, Organisation for Economic Co-operation and Development, World Bank Group, New York, USA, pp. 198.

Vericat $P$, Beltrán $M$, Piqué $M$, Cervera T (2014). Cork oak forests forest typologies and management models. Technical collection "Species and Silviculture", Centre de la Propietat Forestal, Departament d'Agricultura, Ramaderia, Pesca, Alimentació i Medi Natural, Generalitat de Catalunya, Barcelona, Spain, pp. 43.

Wang Y, Goa J, Wang J, Qiu J (2014). Value assessment of ecosystem services in nature reserves in Ningxia, China: a response to ecological restoration. PLoS One 9 (2): e89174. - doi: 10.1371/journal.pone.0089174

West PW (2009). Tree and forest measurement. Springer-Verlag, Berlin-Heidelberg, Germany, pp. 214. - doi: 10.1007/978-3-319-14708-6 Zhu J-J, Matsuzaki T, Lee FQ, Gonda Y (2003). Effect of gap size created by thinning on seedling emergency, survival and establishment in a coastal pine forest. Forest Ecology and Management 182 (1): 339-354. - doi: 10.1016/S03781127(03)00094-X

\section{Supplementary Material}

Tab. S1 - Effect on the economic value of cork production exerted by the different cork quality class proportions and by the variation of quantity (or unitary price) of cork production (values expressed in euro ha-1 $\left.\mathrm{yr}^{-1}\right)$.

Tab. S2 - Effect on the economic value of water yield exerted by the variation of the $K$ coefficient (see text) and by the variation of the unitary price assigned to water yield (values expressed in euro $\mathrm{ha}^{-1} \mathrm{yr}^{-1}$ ).

Fig. S1 - $K$ values of the InVEST water-yield model adopted for pure cork oak forests in Sardinia as a function of stand top height (TH) and number of trees (NT).

Fig. S2 - Annual production of forage units from pure cork oak forests in Sardinia as a function of stand top height (TH) and number of trees (NT).

Fig. S3 - Graphical analysis of the residuals of the established AICORK (expressed in $\mathrm{kg}$ $\mathrm{ha}^{-1} \mathrm{yr}^{-1}$ ) and $A G B$ (expressed in $M g \mathrm{ha}^{-1}$ ) models.

Link: Puletti_2558@supplo01.pdf 